\title{
ISG15 wt Allele
}

National Cancer Institute

\section{Source}

National Cancer Institute. ISG15 wt Allele. NCI Thesaurus. Code C104658.

Human ISG15 wild-type allele is located in the vicinity of $1 \mathrm{p} 36.33$ and is approximately $1 \mathrm{~kb}$ in length. This allele, which encodes ubiquitin-like protein ISG15, plays a role in type I interferon signaling. 